\title{
The contribution of serum hepatitis $B$ virus load in the carcinogenesis and prognosis of hepatocellular carcinoma: evidence from two meta-analyses
}

\author{
Xueqin Chen ${ }^{1,2, *}$, Fan Wu ${ }^{3, *}$, Yanmei Liu ${ }^{4}$, Jiao Lou ${ }^{1}$, Beibei Zhu ${ }^{1}$, Li Zou ${ }^{1}$, Wei Chen ${ }^{1}$, \\ Jing Gong ${ }^{1}$, Ying Wang ${ }^{5}$, Rong Zhong ${ }^{1}$ \\ ${ }^{1}$ Department of Epidemiology and Biostatistics, School of Public Health, Tongji Medical College, Huazhong University of \\ Science and Technology, Wuhan, Hubei, China \\ ${ }^{2}$ Department of Medical Quality Management, Jiangxi Cancer Hospital, Nanchang, Jiangxi, China \\ ${ }^{3}$ Abdominal Surgery Department, Cancer Hospital, Peking Union Medical College, Chinese Academy of Medical Sciences, \\ Beijing, China \\ ${ }^{4}$ Department of Infectious Diseases, Tongji Hospital, Tongji Medical College, Huazhong University of Science and Technology, \\ Wuhan, Hubei, China \\ ${ }^{5}$ Department of Virology, Wuhan Centers for Disease Prevention and Control, Wuhan, Hubei, China \\ *These authors contributed equally to this work \\ Correspondence to: Rong Zhong, email: rongzhong91@gmail.com \\ Ying Wang, email: wangyingxiehe@163.com
}

Keywords: HBV DNA level, hepatocellular carcinoma, hepatocellular carcinoma recurrence, meta-analysis

Received: April 10, 2016

Accepted: June 13, 2016

Published: June 30, 2016

\section{ABSTRACT}

Background and Aim: The meta-analysis aimed to quantify and summarize the contribution of serum hepatitis B virus (HBV) DNA load in the carcinogenesis and prognosis of hepatocellular carcinoma (HCC).

Results: Nine independent studies with a total of 1162 cases and 9365 participants on risk of HCC and seventeen studies with 1342 cases and 2891 participants on recurrence of HCC were finally included. The non-liner dose-response association between HBV DNA level and HCC risk was observed, with $P$ value equal to 0.02 for linear test. Compared with $2 \log _{10}$ copies/ml HBV DNA level carriers, the summary relative risk of HCC were 1.65(95\% CI: 0.94-2.92) for $4.5 \log _{10}$ copies $/ \mathrm{ml}, 2.20(95 \%$ CI: 1.00-4.85) for $5.5 \log _{10}$ copies/ml, 3.06(95\% CI: 1.11-8.44) for $6.5 \log _{10}$ copies $/ \mathrm{ml}$. Moreover, individuals with high viral load (HBV DNA levels $>10^{5} \mathrm{copies} / \mathrm{ml}$ ) presented significant association with increased risk of HCC recurrence, with the pooled RR of 1.69 (95\% CI: 1.49-1.92).

Materials and Methods: Pertinent studies were identified by searching PubMed, Embase and ISI Web of science databases up to January 2016 and by reviewing the references of retrieved articles. The dose-response meta-analysis was precisely performed to calculate the summary relative risks (RRs) by quantizing the association between HBV load and risk of HCC. Besides, the contribution of HBV load on recurrence of HCC was further clarified by general meta-analysis.

Conclusions: These findings indicated a non-linear dose-response relationship between serum HBV DNA level and risk of HCC, and confirmed the significant contribution of serum HBV DNA level in the prognosis of HCC.

\section{INTRODUCTION}

Hepatocellular carcinoma (HCC), a major health challenge worldwide, is the sixth most common cancer [1], and the third leading cause of cancer mortality [2]. The biological mechanisms of pathogenesis and prognosis for HCC were strongly influenced by diverse etiologies involving in both host and viral factors. Among the major risk factors for hepatocarcinogenesis, hepatitis B virus (HBV) infection is of particular importance and has been 
designated as the major etiology of HCC. Throughout the world, approximately 2 billion people suffer from infection of HBV, which would cause a broad spectrum of liver diseases ranging from asymptomatic carrier, chronic hepatitis and liver cirrhosis to HCC [3]. Etiologically, more than $50 \%$ of HCC cases worldwide are attributable to persistent infection of $\mathrm{HBV}$, and reach to $75 \%-85 \%$ of HCC cases in developing countries [4].

HBV DNA load, a sign of active virus replication, which are used to assess the efficacy of the antiviral therapy, has been gradually estimated as an important predisposing factor of HCC [5-7]. More importantly, greater focus has been placed recently on clarifying the role of antiviral therapy in the carcinogenesis of HCC $[8,9]$. However, before figure out the relationship between antiviral therapy and risk of $\mathrm{HCC}$, the detailed effect of HBV DNA load on risk of HCC should be firstly established. Meanwhile, growing evidence from prospective epidemiologic studies is accumulating rapidly to support a very strong relationship between $\mathrm{HBV}$ viral load and risk of HCC. However, the controversial results were yielded by recent previous studies for detailed shape of association between HBV DNA load and risk of HCC. Some previous studies demonstrated that risk of HCC only started to increase significantly at the HBV DNA level of $10^{4}$ copies/ml $[6,10,11]$, in contrast to the findings of Sun et al. [12]. Additionally, some previous studies observed a linear dose-response relationship between HBV DNA load and risk of HCC, but a nonlinear association was also found by other studies which addressed the hazard ratio increased with HBV DNA level in the range of $10^{4}$ to $10^{6}$ copies/ml but abruptly decreased with level $>10^{7}$ copies/ $\mathrm{ml}[13,14]$. Therefore, it has been strongly proposed that the detailed shape of quantitative relationship between HBV DNA level and HCC risk should be systematically evaluated by dose-response meta-analysis to determine the non-linear or linear dose-response association. Moreover, the clarification of the detailed relationship will provide valuable clues to elucidate the important roles of the HBV DNA level in hepatocarcinogenesis.

In addition, the prominent characteristic for $\mathrm{HCC}$ with dismal prognosis is extremely pernicious although the treatment options have been stepped forward. $\mathrm{HCC}$ recurrence is a main obstacle of HCC prognosis, remaining a paramount cause of death in HCC patients [15]. Despite surgical or local regional therapies, the recurrence rates can be as high as $50 \%$ at 2 years $[16,17]$. Consequently, it is of great importance to identify and improve modifiable risk factors to prevent from HCC by considering the malignancy and high recurrence rates of HCC. Theoretically, HCC recurrence may partly be attributable to metachronous multicentric carcinogenesis and de novo HCC [18], which could be enhanced by HBV load. Some of previous studies $[19,20]$ showed that high viral load (HBV DNA levels $>10^{5}$ copies $/ \mathrm{ml}$ ) promotes the recurrence of $\mathrm{HCC}$, but this significant associations were not estimated by Chung et al. [21] and Mathews et al. [22]. Considering the controversial results which have been yielded by previous studies, and the limited power which was estimated by the studies with relatively small sample size, the obscure relationship between HBV load and recurrence of $\mathrm{HCC}$ was urgent to be clarified by a meta-analysis with enough power via combining the basis of published data.

Since HBV DNA load can be alleviated by the treatment of anti-viral agents, it seems important to clarify the exact effect of HBV DNA level on HCC risk and recurrence. The settlement of this problem might somewhat influence the decision of clinically anti-viral treatment for patients with high HBV DNA level. Here we performed a dose-response meta-analysis to discern the potential quantitative association between HBV load and HCC risk. Meanwhile another meta-analysis was also conducted to clarify the controversial relationship between $\mathrm{HBV}$ load and HCC recurrence.

\section{RESULTS}

\section{Literature searches}

The flow chart of literature search on HBV DNA level and HCC risk was shown in Figure 1. A total of 972 publications were totally identified and 935 were excluded after review of title and abstract. After examining the remaining 37 full texts, 30 articles were further excluded owing to the following reasons: only two categories of HBV DNA level $(n=8)$, no evaluation of the relationship between HBV DNA level and HCC risk $(n=13)$, review articles $(n=3)$, lack of necessary information $(n=2)$, and data duplication $(n=4)$. Besides, two additional articles $[14,23]$ were added by looking through the references of the retrieved articles. Therefore, nine studies [5, 6, 10, 11 , 14, 23-25] were included in the final analysis. Similarly, Figure 2 showed the selection procedure of studies on the HBV load and HCC recurrence. The primary searches yielded 983 items, of which 947 articles were removed after scanning the title and abstract. After review of 36 full texts, 10 studies without risk estimation and 8 studies with no report of association between HBV load and HCC recurrence were further excluded. We also removed one report since its interest was HBV DNA titer in surrounding liver. Finally, a total of 17 articles [1, 19-22, 26-37] were pooled into analysis.

\section{Study characteristics}

The detailed information extracted from included studies was shown in Table 1 and Table 2. The doseresponse meta-analysis contained 5 case-control studies with 657 cases and 1595 objects, and 4 cohort studies with $505 \mathrm{HCC}$ patients and 6765 participants totally. All of the studies were conducted in Asia. Furthermore, the 
meta-analysis on HCC recurrence included 1342 cases and 2891 participants. Among the 17 articles, 9 studies were conducted in HCC patients with treatment of tumor resection, and 6 studies in patients with local ablation.

\section{Dose-response meta-analysis of association between HBV DNA level and HCC risk}

We found evidence of non-linear association between HBV DNA level and risk of $\operatorname{HCC}(P=0.02$ for non-linearity). Compared with $2 \log _{10}$ copies/ml HBV DNA level carriers, the summary relative risk of HCC were 1.65 (95\% CI: 0.94-2.92) for $4.5 \log _{10}$ copies $/ \mathrm{ml}, 2.20$ (95\% CI: $1.00-4.85$ ) for $5.5 \log _{10}$ copies $/ \mathrm{ml}, 3.06$ (95\% CI: $1.11-$ 8.44) for $6.5 \log _{10}$ copies/ml. Random-effects model was applied, since moderate heterogeneity between studies was observed $\left(I^{2}=56 \%\right)$ (Figure 3$)$. In the sensitivity analysis, the pooled RRs did not alter essentially, indicating that the summary estimate were reliable and stable. Additionally, no significant publication bias was detected by Egger's test $(P=0.76)$.

\section{Overall meta-analysis of relationship between HBV load and recurrence of $\mathrm{HCC}$}

The overall meta-analysis showed that there was a significant association between HBV DNA load and risk of HCC recurrence, with pooled RR of $1.69(95 \%$
CI: 1.49-1.92) (Figure 4), using fixed-effects model with mild heterogeneity observed $\left(I^{2}=28.8 \%\right)$. Sensitivity analysis indicated that the summary estimate was not influenced by any single study. No evidence of statistically significant publication bias was identified by Egger's test $(P=0.33)$.

\section{Stratified analysis of relationship between $\mathrm{HBV}$ load and $\mathrm{HCC}$ recurrence}

Stratified analyses were performed to explore the source of heterogeneity and examine the stability of the primary results (Table 3 ). When we conducted stratified analysis according to median duration of follow-up, study style and primary treatment method, the contribution of HBV load to HCC recurrence for all subgroups was similar to that for the overall analysis. The heterogeneity between studies was not greatly reduced in the subgroups.

\section{DISCUSSION}

The current meta-analysis on risk of HCC indicated that there was a non-linear dose-response association between HBV DNA level and HCC risk. The RRs of HCC increased with HBV DNA lever, and leveled up at heavy HBV DNA load. Our study, to the best of knowledge, firstly explores the precise effect of HBV DNA level on $\mathrm{HCC}$ risk based on a non-linear dose-response

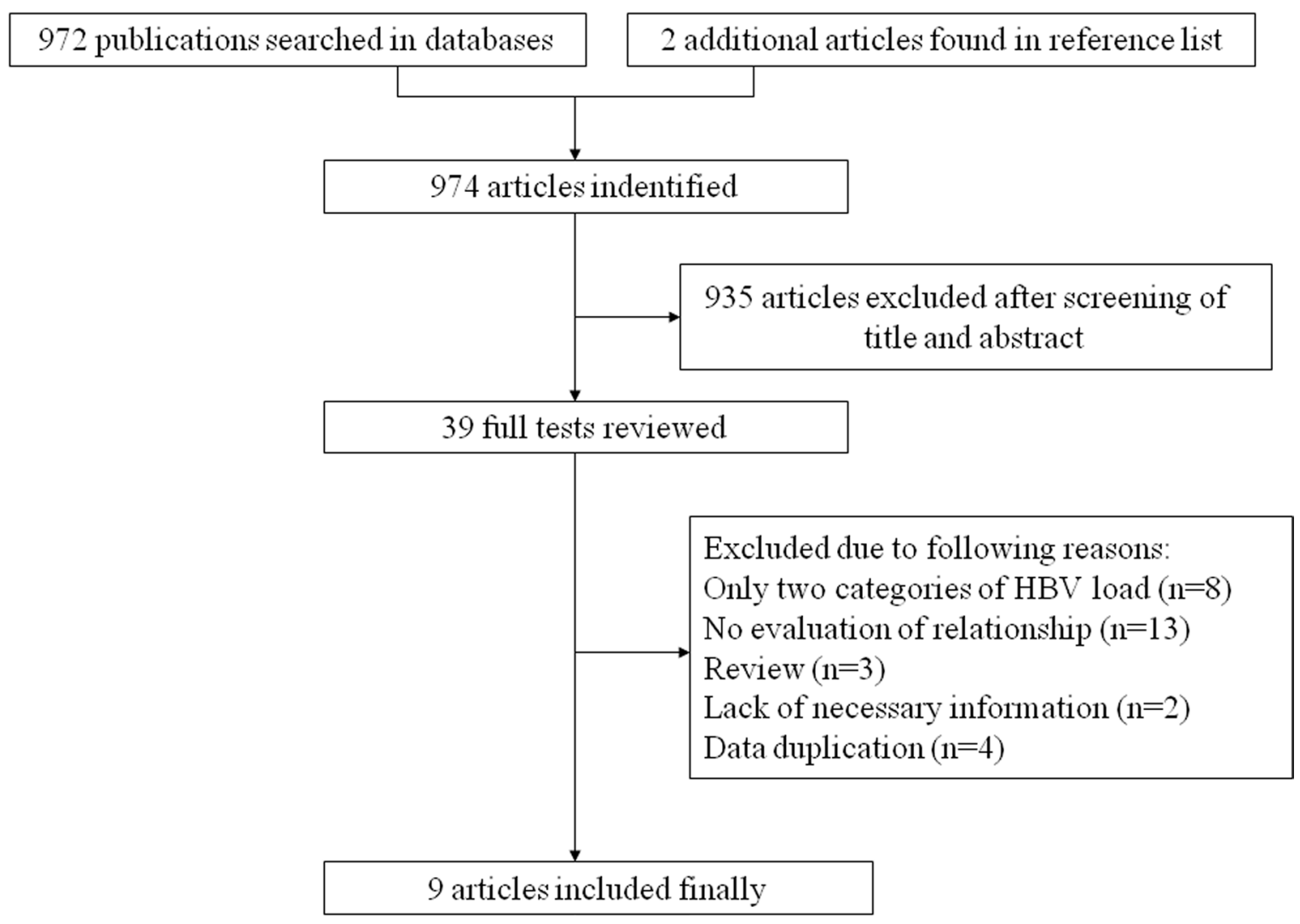

Figure 1: The flow chart of literature search on HBV DNA level and HCC risk. 
Table 1: Characteristics of studies on HBV DNA level and HCC risk

\begin{tabular}{|c|c|c|c|c|c|c|c|c|c|}
\hline Study & $\begin{array}{c}\text { Publication } \\
\text { year }\end{array}$ & $\begin{array}{c}\text { Study } \\
\text { location }\end{array}$ & Study design & $\begin{array}{l}\text { No of } \\
\text { cases }\end{array}$ & $\begin{array}{c}\text { Sample } \\
\text { size/person } \\
\text { years }\end{array}$ & $\begin{array}{l}\text { HBV DNA level } \\
\left(\log _{10} \operatorname{copies} / \mathrm{ml}\right)\end{array}$ & $\begin{array}{c}\text { Adjusted } \\
\text { RR }\end{array}$ & $95 \%$ CI & Adjustment variables \\
\hline \multirow[t]{5}{*}{$\mathrm{Yu}$} & 2005 & Taiwan & Case-control & 154 & 470 & UD & 1.00 & & \multirow{5}{*}{$\begin{array}{l}\text { Age, date of blood collection, } \\
\text { ethnicity, history of cigarette } \\
\text { smoking and alcohol drinking }\end{array}$} \\
\hline & & & & & & $3.62-4.22$ & 1.07 & $0.44-2.60$ & \\
\hline & & & & & & $4.23-4.90$ & 2.54 & $1.16-5.59$ & \\
\hline & & & & & & $4.91-5.90$ & 2.44 & $1.12-5.28$ & \\
\hline & & & & & & $5.91-10.81$ & 7.26 & $3.54-14.89$ & \\
\hline \multirow[t]{6}{*}{ Liu } & 2008 & China & Case-control & 170 & 446 & UD & 1.00 & & \multirow{6}{*}{$\begin{array}{l}\text { Age, cigarette smoking, alcohol } \\
\text { consumption, and family history } \\
\text { of chronic liver diseases }\end{array}$} \\
\hline & & & & & & $2.69-3.99$ & 0.47 & $0.17-1.256$ & \\
\hline & & & & & & $4.00-4.99$ & 2.83 & $1.24-6.49$ & \\
\hline & & & & & & $5.00-5.99$ & 48.40 & $14.39-162.79$ & \\
\hline & & & & & & $6.00-6.99$ & 42.25 & $14.78-120.75$ & \\
\hline & & & & & & $\geq 7.00$ & 14.82 & $6.99-31.41$ & \\
\hline \multirow[t]{6}{*}{$\mathrm{Xu}$} & 2009 & China & Case-control & 155 & 310 & $<3.00$ & 1.00 & & None \\
\hline & & & & & & $3.00-4.00$ & 1.34 & $0.55-3.30$ & \\
\hline & & & & & & $4.00-5.00$ & 2.39 & $1.13-5.05$ & \\
\hline & & & & & & $5.00-6.00$ & 2.61 & $1.18-5.77$ & \\
\hline & & & & & & $6.00-7.00$ & 2.05 & $0.97-4.33$ & \\
\hline & & & & & & $\geq 7.00$ & 1.28 & $0.46-3.54$ & \\
\hline \multirow[t]{3}{*}{ Asim } & 2010 & India & Case-control & 88 & 188 & $\leq 4.50$ & 1.00 & & \multirow{3}{*}{$\begin{array}{l}\text { Age, sex, } \mathrm{HBeAg} \text { status, } \\
\text { genotype, mutations in the } \mathrm{X} \\
\text { region, mutations in the } \mathrm{BCP} \\
\text { region, mutations in the precore } \\
\text { region, mutations in the core } \\
\text { region }\end{array}$} \\
\hline & & & & & & $4.50-6.50$ & 2.27 & $1.13-4.58$ & \\
\hline & & & & & & $>6.50$ & 2.62 & $1.06-6.45$ & \\
\hline \multirow[t]{5}{*}{ Zhou } & 2012 & China & Case-control & 90 & 180 & $<3.00$ & 1.00 & & None \\
\hline & & & & & & $3.00-4.00$ & 1.38 & $0.54-3.50$ & \\
\hline & & & & & & $4.00-5.00$ & 3.67 & $1.36-9.89$ & \\
\hline & & & & & & $5.00-6.00$ & 5.30 & $1.85-15.28$ & \\
\hline & & & & & & $\geq 6.00$ & 3.03 & $1.14-8.04$ & \\
\hline \multirow[t]{5}{*}{ Chen } & 2006 & Taiwan & Cohort & 164 & 41779 & $<2.48$ & 1.00 & & \multirow{5}{*}{$\begin{array}{l}\text { Sex, age, cigarette and alcohol } \\
\text { use, HBeAg, ALT level, and } \\
\text { cirrhosis at entry }\end{array}$} \\
\hline & & & & & & $2.48-4.00$ & 1.10 & $0.25-2.30$ & \\
\hline & & & & & & $4.00-5.00$ & 2.30 & $1.10-4.90$ & \\
\hline & & & & & & $5.00-6.00$ & 6.60 & $3.30-13.10$ & \\
\hline & & & & & & $>6.00$ & 6.10 & $2.90-12.70$ & \\
\hline \multirow[t]{3}{*}{ Wong } & 2010 & Hongkong & Cohort & 45 & 424 & $<4.50$ & 1.00 & & None \\
\hline & & & & & & $4.50-6.50$ & 1.97 & $0.80-4.83$ & \\
\hline & & & & & & $>6.50$ & 2.88 & $1.23-6.77$ & \\
\hline \multirow[t]{3}{*}{ Wong } & 2010 & Hongkong & Cohort & 105 & 1005 & $<4.50$ & 1.00 & & \multirow{3}{*}{$\begin{array}{l}\text { Age,sex,albumin,bilirubin, } \mathrm{AL} \\
\text { T,radiologic cirrhosis, antiviral } \\
\text { therapy }\end{array}$} \\
\hline & & & & & & $4.50-6.50$ & 1.83 & $1.03-3.25$ & \\
\hline & & & & & & $>6.50$ & 3.40 & $1.97-5.87$ & \\
\hline \multirow[t]{5}{*}{ Tseng } & 2012 & Taiwan & Cohort & 191 & 39427 & $<3.00$ & 1.00 & & \multirow[t]{5}{*}{ None } \\
\hline & & & & & & $3.00-4.00$ & 0.90 & $0.40-1.90$ & \\
\hline & & & & & & $4.00-5.00$ & 2.00 & $1.00-3.90$ & \\
\hline & & & & & & $5.00-6.00$ & 4.10 & $2.10-8.00$ & \\
\hline & & & & & & $>6.00$ & 5.10 & $2.80-9.20$ & \\
\hline
\end{tabular}

Abbreviations: HBV, hepatitis B virus; HBeAg, hepatitis B e antigen; HCC, hepatocellular carcinoma; RR, relative risk; CI, confidence interval; UD, undetectable; BCP, basal core promoter; ALT, alanine aminotranferase.

relationship. Another overall meta-analysis confirmed the significant contribution of serum HBV DNA level in the recurrence of HCC, which would provide robust evidence for this controversial problem.

To date, the majority of studies have showed the risk of HCC increasing gradually with the augment of HBV load, albeit the positive cut off point were slightly different. However, Xu [14] and colleagues designed a matched case-control study and found that the RRs of HCC turned non-significant at high HBV DNA level. One potential explanation for this null association might be related to limited sample size in higher category of HBV DNA. In our study, the HCC risk started to increased significantly at HBV DNA level of $5 \log _{10}$ copies $/ \mathrm{ml}$, which was similar to the level suggested by current clinical practice guidelines for making management 
Table 2: Characteristics of studies on $\mathrm{HBV}$ load and recurrence of $\mathrm{HCC}$

\begin{tabular}{|c|c|c|c|c|c|c|c|c|}
\hline Author & $\begin{array}{c}\text { Publication } \\
\text { year }\end{array}$ & $\begin{array}{c}\text { Study } \\
\text { location }\end{array}$ & Treatment & $\begin{array}{l}\text { No of } \\
\text { cases }\end{array}$ & $\begin{array}{c}\text { No of } \\
\text { participants }\end{array}$ & $\begin{array}{l}\text { Adjusted } \\
\text { RR }\end{array}$ & $95 \% \mathrm{CI}$ & Adjustment for covariates \\
\hline Jang & 2007 & Korea & TACE & 32 & 62 & 3.77 & $1.70-8.38$ & $\begin{array}{l}\text { HBeAg status, Child-Pugh } \\
\text { classification, No. of tumors, } \\
\text { lamivudine use }\end{array}$ \\
\hline Kim & 2008 & Korea & Resection & 75 & 157 & 1.61 & $1.01-2.55$ & $\begin{array}{l}\text { Tumor size, tumor number, } \\
\text { vascular invasion, and } \\
\text { grades }\end{array}$ \\
\hline Chuma & 2009 & Japan & $\begin{array}{l}\text { Resection or } \\
\text { RFA }\end{array}$ & 38 & 64 & 2.67 & $1.31-5.47$ & $\begin{array}{l}\text { Gender, age, HBeAg status, } \\
\text { ALT, Platelet count, PT, } \\
\text { Albumin, Bilirubin, Liver } \\
\text { fibrosis, tumor differentiation, } \\
\text { AFP, PIVKA-II, tumor size } \\
\text { tumor number initial treatment }\end{array}$ \\
\hline $\mathrm{Wu}$ & 2009 & Taiwan & Resection & 39 & 92 & 2.55 & $1.04-6.24$ & $\begin{array}{l}\text { Ishak activity, } \\
\text { multinodularity,ICG-15 }\end{array}$ \\
\hline $\mathrm{Qu}$ & 2010 & China & Resection & 183 & 317 & 2.11 & $1.48-3.00$ & $\begin{array}{l}\text { Alpha-fetoprotein, } \\
\text { microvascular, invasion, } \\
\text { postoperative IFN- } \alpha \text { treatment }\end{array}$ \\
\hline Liang & 2010 & China & Resection & 38 & 64 & 1.80 & $0.80-4.11$ & None \\
\hline An & 2010 & Korea & Resection & 95 & 188 & 1.80 & $0.85-3.80$ & $\begin{array}{l}\text { ALT, Child-Pugh class B, } \\
\text { HBeAg seropositivity, vascular } \\
\text { invasion, cirrhosis, tumor size }\end{array}$ \\
\hline Goto & 2011 & Japan & RFA & 42 & 69 & 2.67 & $1.16-6.14$ & $\begin{array}{l}\text { Albumin, Platelet count, } \\
\text { prothrombin activity, Child- } \\
\text { Pugh Class, number of nodules }\end{array}$ \\
\hline Chung & 2011 & Korea & Local ablation & 63 & 140 & 1.02 & $0.61-1.71$ & None \\
\hline $\mathrm{Li}$ & 2011 & China & OLT & 43 & 148 & 2.45 & $1.10-5.45$ & $\begin{array}{l}\text { Age, gender, number of } \\
\text { nodules, the largest nodule } \\
\text { size, exceeding Milan criteria, } \\
\text { vascular invasion, tumor } \\
\text { differentiation, preoperative } \\
\text { serum AFP level, HBV } \\
\text { recurrence }\end{array}$ \\
\hline $\mathrm{Xia}$ & 2012 & China & RFA & 67 & 152 & 1.73 & $0.88-3.40$ & None \\
\hline Mathews & 2012 & Korea & Resection & 99 & 247 & 1.01 & $0.50-2.02$ & $\begin{array}{l}\text { Age, gender, serum AFP, serum } \\
\text { ALT, advanced MELD score, } \\
\text { tumor size, microvascular } \\
\text { invasion, advanced CLIP stage, } \\
\text { E-S grade }\end{array}$ \\
\hline $\mathrm{Su}$ & 2013 & Taiwan & Resection & 208 & 333 & 1.43 & $1.05-1.95$ & $\begin{array}{l}\text { GGT, macroscopic venous } \\
\text { invasion, microscopic venous } \\
\text { invasion }\end{array}$ \\
\hline Kim & 2014 & Korea & RFA & 70 & 300 & 1.55 & $0.79-3.03$ & None \\
\hline Sohn & 2014 & Korea & RFA & 89 & 170 & 1.57 & $1.02-2.41$ & Multinodularity, BCLC stage \\
\hline Sohn & 2014 & Korea & Resection & 61 & 188 & 2.77 & $1.62-4.73$ & $\begin{array}{l}\text { Age, sex, Platelet, ALT, AFP, } \\
\text { DCP, HBeAg, }\end{array}$ \\
\hline Hung & 2016 & $\begin{array}{l}\text { Hong } \\
\text { Kong }\end{array}$ & Resection & 100 & 200 & 1.67 & $1.09-2.57$ & $\begin{array}{l}\text { AFP, tumor size, antiviral } \\
\text { treatment, tumor differentiation, } \\
\text { lymphovascular permeation, } \\
\text { microsatellite lesions }\end{array}$ \\
\hline
\end{tabular}

Abbreviations: HBV, hepatitis B virus; HCC, hepatocellular carcinoma; RR, relative risk; CI, confidence interval; TACE, transarterial chemolipiodoization, HBeAg, hepatitis B e antigen; AFP, alpha-fetoprotein; RFA, radiofrequency ablation; ALT, alanine aminotranferase; PT, prothrombin time; PIVKA-II, protein induced by vitamin K absence or antagonist II; ICG-15, indocyanine green 15-min retention rate; OLT, orthotopic liver transplantation; MELD, Model for End-Stage Liver Disease; BCP, basal core promoter; CLIP, Cancer of the Liver Italian Program; E-S grade, Edmondson-Steiner grade; GGT, $\gamma$-glutamyl transpeptidase; BCLC, Barcelona Clinic Liver Cancer; DCP, des- $\gamma$-carboxy prothrombin. 
decisions in the care of chronic hepatitis B patients. Moreover, our study also showed that the patients after primary therapy with high HBV load are more likely to suffer the recurrence of HCC. The similar results were also demonstrated in stratified analyses. When we carried out the stratified analysis based on the median duration of follow-up, heterogeneity reduced obviously with $I^{2}$ down to $19.4 \%$ in longer duration of follow-up studies. For HCC patients, most recurrence happened within two years, but there were still several smaller clusters of recurrences after two years [26]. Therefore, studies with shorter followup duration were unable to discover these patients who tended to late recurrence, leading to the different effect size derived from two subgroups. This may potentially explanted that some studies [30, 35] failed to disclose the positive relationship between HBV load and HCC recurrence. When stratified by study style, heterogeneity disappeared in the retrospective studies. Similar results were observed in both prospective and retrospective subgroups. The difference in effect size between the two groups could be probably caused by its own particular characteristics of each study design. Furthermore, stratified analysis was conducted by primary treatment. Heterogeneity remained unchanged or mildly increased after stratified by treatment. The results of subgroups were similar with overall analysis. Taken together antiviral therapy after tumor resection and RFA, when HBV DNA load is heavy, will produce substantially beneficial effect on the long-term prognosis of HBV related HCC patients.

The carcinogenic mechanisms of $\mathrm{HBV}$ are as follows. First, HBV DNA can integrate into hepatic cell randomly, which may induce chromosomal deletions and other genetic instability, contributing to HCC [38]. Moreover, cellular genes integrated with HBV DNA encode products with alterative structures, disrupting the crucial functions such as regulating cell signaling and controlling cell proliferation [39]. Second, HBx, a product encoded by $\mathrm{HBV} \mathrm{X}$ gene, is involved to stimulate certain oncogenes and activate several signal pathways related to cell proliferation and cell apoptosis, leading to hepatocarcinogenesis [40]. Third, dynamic HBV replication may trigger chronic hepatopathy with gangrenous inflammation. As a result, a series of reaction from the inflammatory process can induce genomic changes and accelerate the development of HCC [41]. Although the precise mechanism of $\mathrm{HCC}$ recurrence related to $\mathrm{HBV}$ is not clearly elucidated, some previous studies have demonstrated that a high HBV viral load

\section{3 articles found in database search}

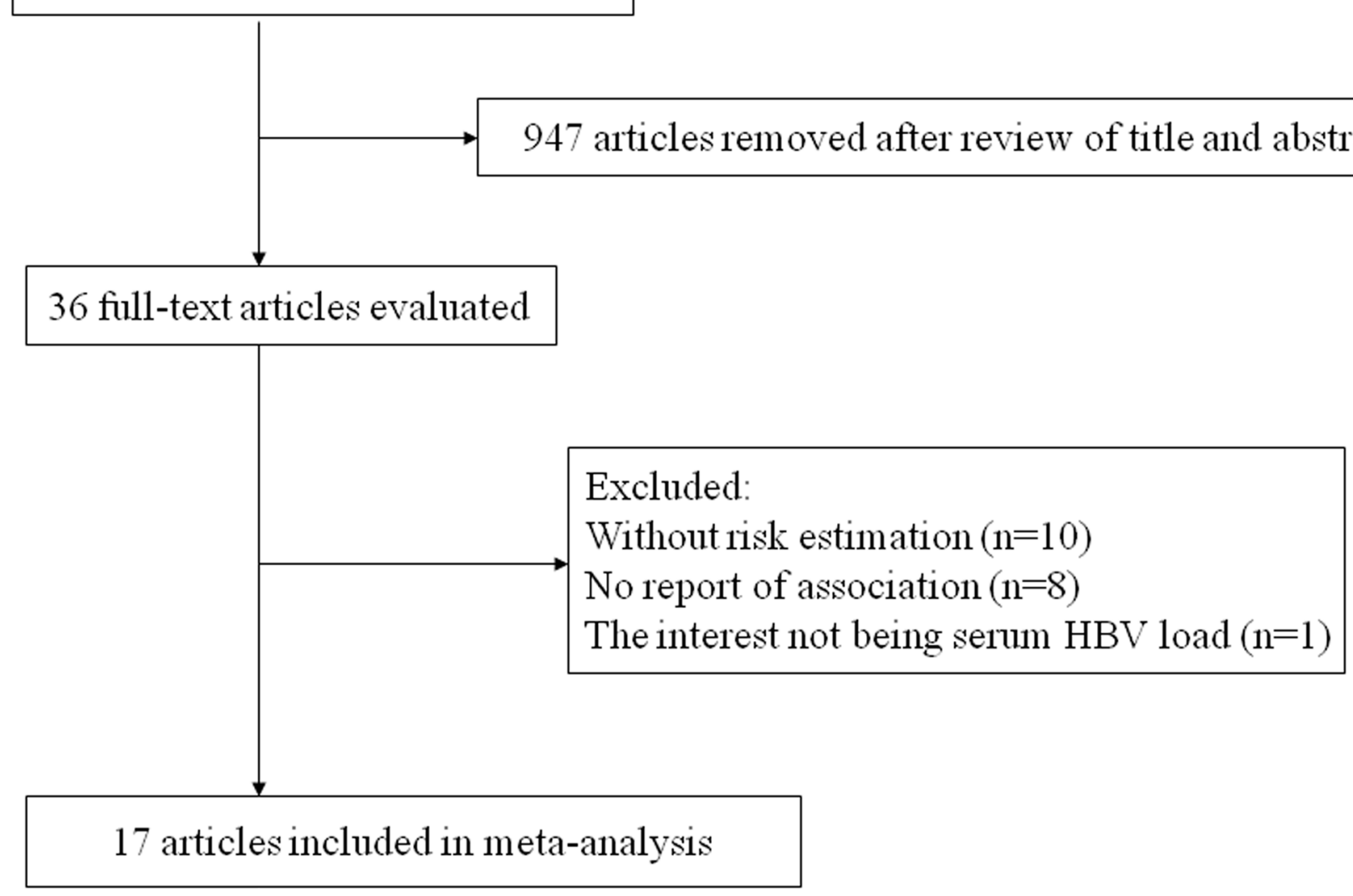

Figure 2: The selection procedure of studies on the $\mathrm{HCC}$ recurrence. 
Table 3: Pooled RRs with 95\% CIs for the association between HBV DNA load and HCC recurrence by stratified analysis

Stratified factors
\begin{tabular}{|l|c|c|c|c|c|}
\hline Median duration of follow-up of reports & RR (95\% CI) & P for heterogeneity & \multicolumn{1}{l}{$\boldsymbol{\text { (\%) }}$} & $P$ for test \\
\hline$\geq 36$ months & 3 & $1.62(1.17-2.27)$ & 0.29 & 19.4 & 0.004 \\
\hline$<36$ months & 14 & $1.81(1.43-2.30)$ & 0.02 & 50.7 & 0.000 \\
\hline Study style & 8 & $1.73(1.13-2.65)$ & 0.01 & 65.2 & 0.011 \\
\hline Prospective & 9 & $1.83(1.55-2.15)$ & 0.46 & 0.0 & 0.000 \\
\hline Retrospective & 9 & $1.71(1.29-2.27)$ & 0.02 & 56.1 & 0.000 \\
\hline Primary treatment & 9 & $1.73(1.23-2.44)$ & 0.12 & 43.3 & 0.002 \\
\hline Resection & 5 &
\end{tabular}

could cause malignant transformations in the remnant liver, which was similar with the mechanism of HCC, thus facilitating intrahepatic metastases or multicentric carcinogenesis, and then lead to recurrent tumor [42, 43].

The current study has its own strengths. First, we examined the shape of dose-response relationship between HBV DNA level and risk of HCC. Linear and non-linear trend were both evaluated to disclose the authentic association. Second, the significant relationship between HBV load and HCC recurrence was verified by metaanalysis, which could provide high statistical power by integrating independent studies with relative large sample size. Third, we evaluated the effect of HBV load not only on risk of $\mathrm{HCC}$, but also on $\mathrm{HCC}$ recurrence, emphasizing the importance of antiviral treatment for chronic HBV infection patients to undergo a better outcome.

In spite of these advantages mentioned above, several limitations should also be acknowledged. First, the confounding factors which exited in every independent study cannot be settled in the meta-analysis, although most studies adjusted the main reported confounders or controlled them in the selection of participants. Second, we failed to evaluate

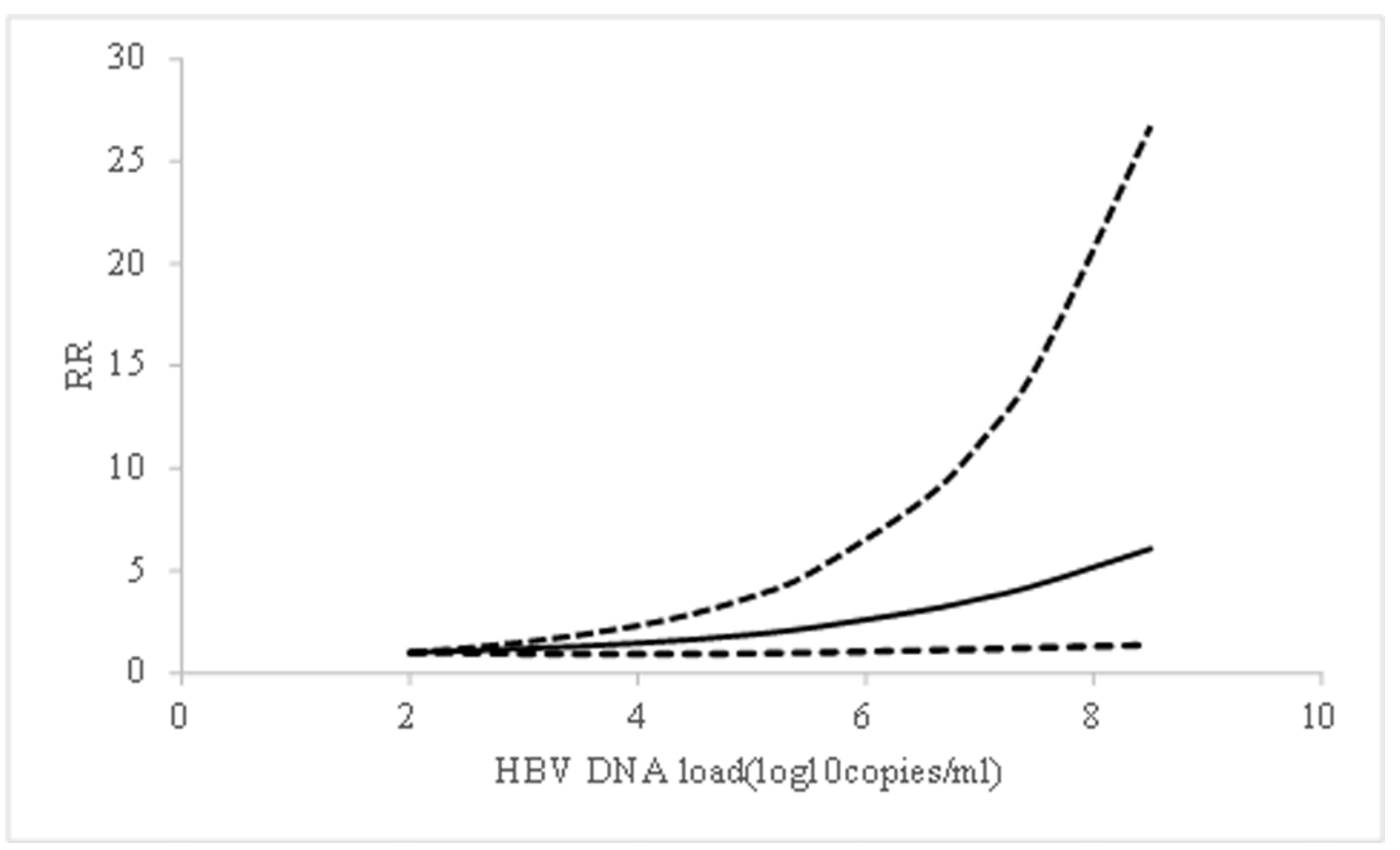

Figure 3: The shape of association between HBV DNA level and HCC risk, with restricted cubic splines in randomeffects dose-response model. The solid line and the short dash line represent the estimated relative risks and corresponding $95 \%$ CIs, respectively. 
the effect of high HBV load on HCC recurrence in subgroups of patients after transtarterial chemolipiodolization and orthotopic liver transplantation owing to the limited data. Third, even though we attempted to excavate the source of between-study heterogeneity existed in the dose-response meta-analysis, the results seemed to be regretful.

To our knowledge, the HBV infection is a global public health problem, particularly in epidemic regions such as East and Southeast Asia and sub-Saharan Africa $[3,44]$. More importantly, the incidence of HBV related $\mathrm{HCC}$ has been increasing. The effect of high HBV load on both $\mathrm{HCC}$ risk and recurrence estimated in our metaanalyses would encourage the use of anti-viral therapy for both chronic hepatitis $\mathrm{B}$ and $\mathrm{HCC}$ patients to reduce $\mathrm{HBV}$ DNA level, aiming to decrease the incidence rate of $\mathrm{HCC}$ and improve the prognosis of HCC patients. Although the sound evidence of potential benefit of this strategy would come from the randomized controlled tests of antiviral agents, our study may provide robust etiological basis. In summary, this study not only identified the non-linear doseresponse association between HBV DNA level and risk of HCC, but also revealed the contribution of high HBV load on HCC recurrence. Further studies with large sample size and well design are warranted to confirm our results.

\section{MATERIALS AND METHODS}

\section{Search strategy and literature selection}

We performed a literature search of PubMed, Embase and ISI Web of science databases from their inceptions to January 2016 using the key words "HBV DNA level or HBV load" and "hepatocellular carcinoma" for the dose-response meta-analysis. The same strategy

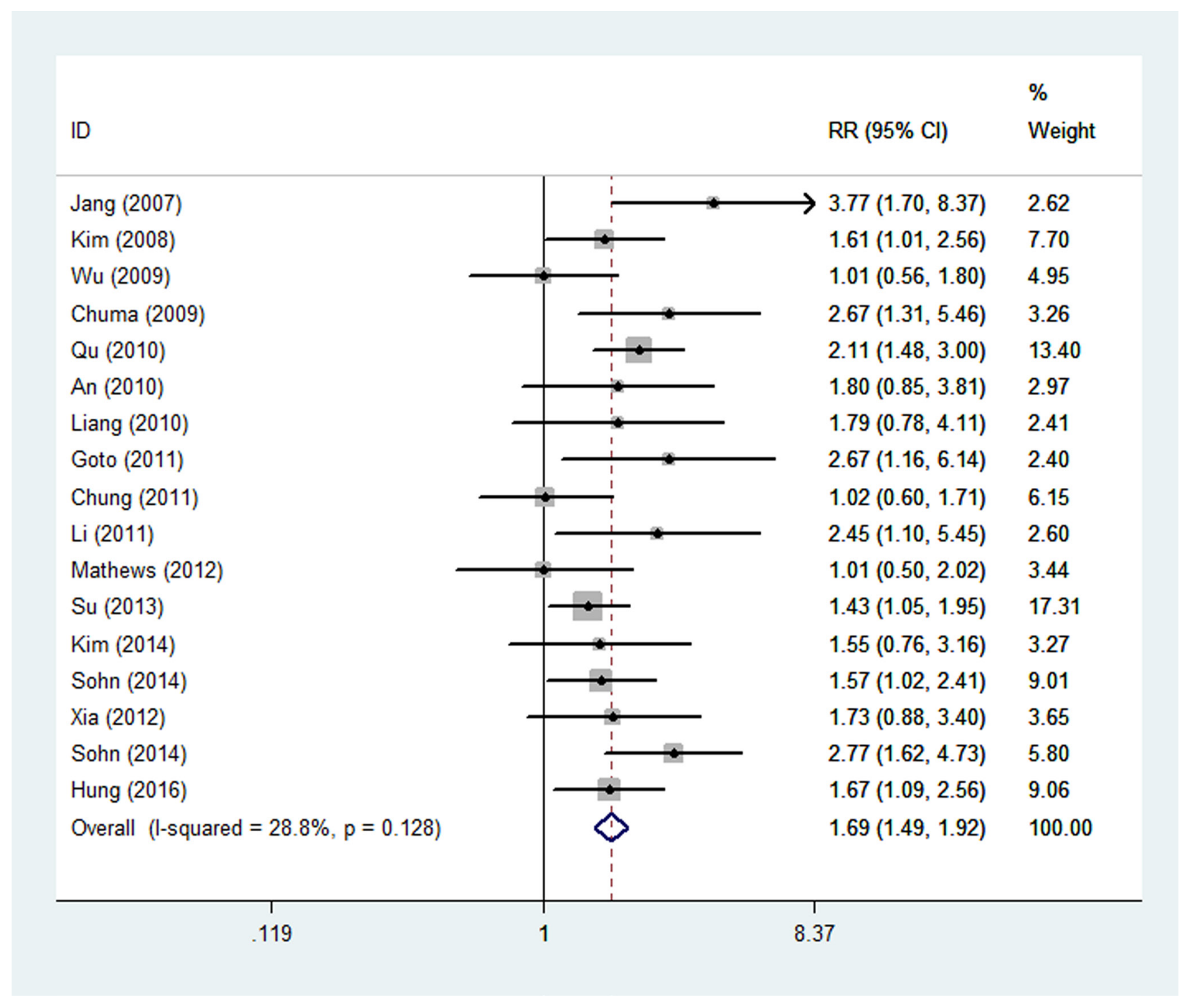

Figure 4: The forest figure of overall meta-analysis on $\mathrm{HBV}$ load and recurrence of $\mathrm{HCC}$. 
was applied to search for articles on HCC recurrence with the key words "HBV" and "hepatocellular carcinoma recurrence". The searches were limited to studies conducted in humans, and no language restrictions were imposed. Furthermore, the reference lists of retrieved articles were also reviewed to identify the additional studies. We conducted the meta-analysis and reported its results following the standard criteria [45].

The following criteria were applied into the literature selection for the dose-response meta-analysis on HBV DNA level and HCC risk: (1) the study had a case-control, nested case-control or cohort design; (2) the investigators assessed the relationship between multiple quantitative categories of HBV DNA level and risk of HCC; (3) the number of cases, the total subjects or personyears and corresponding odds radios (ORs), RRs or hazard ratios (HRs) together with 95\% confidence interval (CI) for each category were provided. Studies on recurrence of HCC were included in another meta-analysis if they satisfied the following criteria: (1) the study had a cohort study design; (2) the study of interest was serum HBV load; (3) the overcome of interest was the incidence of HCC recurrence; (4) the RR estimates with 95\% CIs were reported or available to be calculated.

\section{Data extraction}

Data were extracted independently by two reviewers and cross-checked to resolve any discrepancies. The following information were extracted from each study: first author, publication year, study location, number of cases, sample size or person-years, categories of HBV DNA level, relevant RR and 95\% CI, and covariates adjusted for in the multivariable analysis.

For each study, the median or mean HBV DNA level for every category was assigned to corresponding relative risk. When the median or mean value per category was not provided in the article, we assigned the midpoint of the upper and lower boundary in each category as the average level. If the upper or lower boundary was open-ended, we assumed that the boundary had the same amplitude as the adjacent category.

\section{Statistical analysis}

All of HBV DNA levels were $\log _{10}$-transformed to normalize and unify the data and the quantitative unit was copies $/ \mathrm{ml}$. If the reported unit was IU/ml, we assumed that one IU was approximately equivalent to five copies according to the current World Health Organization HBV standard and consensus [46]. RR and the corresponding 95\% CI were calculated to estimate the effect of HBV DNA level on HCC. Since the morbidity of HCC is relatively low among general population, the OR extracted from case-control studies is pretty close to RR. Thus, we reported all results as RR for briefness.
We conducted a dose-response meta-analysis of the association between HBV DNA level and HCC risk, using the method for trend estimation proposed by Greenland and Longnecker [47]. To examine the potential nonlinear relationship between them, we created restricted cubic splines with three knots at percentiles 10\%, 50\% and $90 \%$ of the distribution. A probability value for nonlinearity was calculated by testing the null hypothesis that the coefficient of the second spline was equal to zero. Between-study heterogeneity was evaluated by the $I^{2}$ statistic $\left(I^{2}<30 \%\right.$, no between-study heterogeneity or marginal heterogeneity; $I^{2}=30 \%-70 \%$, mild heterogeneity; $I^{2}>70 \%$, notable heterogeneity) [48]. A fixed effect model (Mantel-Haenszel method) was applied if heterogeneity was negligible, and random effect model (DerSimonian and Laird method) if heterogeneity was significant [49]. We conducted the overall meta-analysis and stratified analysis according to relevant covariates. In order to assess the influence of single data set on the whole estimate, we performed sensitivity analysis by omitting each study at a time. In addition, the publication bias was evaluated by Egger's test. All statistical analyses were conducted by Stata version 11 and a two-tailed $P<0.05$ was considered to be statistically significant.

\section{ACKNOWLEDGMENTS AND FUNDING}

We thank all the people who help us accomplish this research. This work was supported by General and Special Financial Grant from the China Postdoctoral Science Foundation [2014M550395, 2015T80808 to R. Z.], and [2014M552049 to J.G.], and Innovative Talent Development Project for Y.W.

\section{CONFLICTS OF INTEREST}

The authors disclose no conflicts of interest.

\section{REFERENCES}

1. Xia F, Lai EC, Lau WY, Ma K, Li X, Bie P, Qian C. High serum hyaluronic acid and hbv viral load are main prognostic factors of local recurrence after complete radiofrequency ablation of hepatitis b-related small hepatocellular carcinoma. Ann Surg Oncol. 2012; 19:1284-1291.

2. Parkin DM, Bray F, Ferlay J, Pisani P. Estimating the world cancer burden: Globocan 2000. Int J Cancer. 2001; 94: 153-156.

3. Lavanchy D. Hepatitis b virus epidemiology, disease burden, treatment, and current and emerging prevention and control measures. J Viral Hepat. 2004; 11:97-107.

4. Parkin DM, Bray F, Ferlay J, Pisani P. Global cancer statistics, 2002. CA Cancer J Clin. 2005; 55:74-108.

5. Chen CJ, Yang HI, Su J, Jen CL, You SL, Lu SN, Huang GT, Iloeje UH. Risk of hepatocellular carcinoma 
across a biological gradient of serum hepatitis b virus DNA level. JAMA. 2006; 295:65-73.

6. Zhou JY, Zhang L, Li L, Gu GY, Zhou YH, Chen JH. High hepatitis $b$ virus load is associated with hepatocellular carcinomas development in chinese chronic hepatitis $b$ patients: A case control study. Virol J. 2012; 9:16.

7. Mommeja-Marin H, Mondou E, Blum MR, Rousseau F. Serum hbv DNA as a marker of efficacy during therapy for chronic hbv infection: Analysis and review of the literature. Hepatology. 2003; 37:1309-1319.

8. Yapali S, Lok AS. Does suppression of hbv replication by antiviral therapy confer the same benefit as host immune control of hbv? Gut 2014; 63:1833-1834.

9. Thiele M, Gluud LL, Dahl EK, Krag A. Antiviral therapy for prevention of hepatocellular carcinoma and mortality in chronic hepatitis b: Systematic review and meta-analysis. BMJ open. 2013; 3:e003265.

10. Yu MW, Yeh SH, Chen PJ, Liaw YF, Lin CL, Liu CJ, Shih WL, Kao JH, Chen DS, Chen CJ. Hepatitis b virus genotype and DNA level and hepatocellular carcinoma: A prospective study in men. J Natl Cancer Inst. 2005; 97:265-272.

11. Liu TT, Fang Y, Xiong H, Chen TY, Ni ZP, Luo JF, Zhao NQ, Shen XZ. A case-control study of the relationship between hepatitis $\mathrm{b}$ virus DNA level and risk of hepatocellular carcinoma in qidong, china. World J Gastroenterol. 2008; 14:3059-3063.

12. Sun Y, Chen TY, Lu PX, Wang JB, Wu Y, Zhang QN, Qian GS, Tu H. Relationship between serum hepatitis b virus DNA load and hepatocellular carcinoma in qidong, china: A cohort follow-up study of 14 years. [Article in Chinese]. Zhonghua Yi Xue Za Zhi. 2012; 92:1874-1877.

13. Chen CF, Lee WC, Yang HI, Chang HC, Jen CL, Iloeje UH, Su J, Hsiao CK, Wang LY, You SL, Lu SN, Chen CJ. Changes in serum levels of hbv DNA and alanine aminotransferase determine risk for hepatocellular carcinoma. Gastroenterology. 2011; 141:1240-1248.

14. Xu J, Lin Y, Wang YP, Chen YX, Shi B, Lu J, Xie WF. Hepatitis b virus DNA in patients with hepatitis b-related liver cirrhosis with or without hepatocellular carcinomas: A matched case-control study. J Dig Dis. 2009; 10:138-144.

15. Hoshida Y, Villanueva A, Kobayashi M, Peix J, Chiang DY, Camargo A, Gupta S, Moore J, Wrobel MJ, Lerner J, Reich M, Chan JA, Glickman JN, et al. Gene expression in fixed tissues and outcome in hepatocellular carcinoma. N Engl J Med. 2008; 359:1995-2004.

16. Nagasue N, Uchida M, Makino Y, Takemoto Y, Yamanoi A, Hayashi T, Chang YC, Kohno H, Nakamura T, Yukaya H. Incidence and factors associated with intrahepatic recurrence following resection of hepatocellular carcinoma. Gastroenterology. 1993; 105:488-494.

17. Poon RT, Fan ST, Lo CM, Liu CL, Wong J. Intrahepatic recurrence after curative resection of hepatocellular carcinoma: Long-term results of treatment and prognostic factors. Ann Surg. 1999; 229:216-222.
18. Koike K, Tsutsumi T, Fujie H, Shintani Y, Kyoji M. Molecular mechanism of viral hepatocarcinogenesis. Oncology. 2002; 62:29-37.

19. Goto $\mathrm{T}$, Yoshida $\mathrm{H}$, Tateishi $\mathrm{R}$, Enooku $\mathrm{K}$, Goto $\mathrm{E}$, Sato T, Ohki T, Masuzaki R, Imamura J, Shiina S, Koike K, Omata M. Influence of serum hbv DNA load on recurrence of hepatocellular carcinoma after treatment with percutaneous radiofrequency ablation. Hepatol Int. 2011; 5:767-773.

20. Kim BK, Park JY, Kim do Y, Kim JK, Kim KS, Choi JS, Moon BS, Han KH, Chon CY, Moon YM, Ahn SH. Persistent hepatitis b viral replication affects recurrence of hepatocellular carcinoma after curative resection. Liver Int. 2008; 28:393-401.

21. Chung GE, Kim W, Lee JH, Kim YJ, Yoon JH, Lee JM, Lee JY, Kim SH, Kim D, Lee HS. Negative hepatitis b envelope antigen predicts intrahepatic recurrence in hepatitis b virus-related hepatocellular carcinoma after ablation therapy. J Gastroenterol Hepatol. 2011; 26:1638-1645.

22. Mathews P, Lee D, Chung YH, Kim JA, Lee JH, Jin YJ, Park W, Lyu H, Jaffee E, Zheng L, Yu E, Lee YJ. Effects of genomic changes in hepatitis $b$ virus on postoperative recurrence and survival in patients with hepatocellular carcinoma. Ann Surg Oncol. 2012; 20:1216-1222.

23. Asim M, Malik A, Sarma MP, Polipalli SK, Begum N, Ahmad I, Khan LA, Husain SA, Akhtar N, Husain S, Thayumanavan L, Singla R, Kar P. Hepatitis b virus bcp, precore/core, $\mathrm{x}$ gene mutations/genotypes and the risk of hepatocellular carcinoma in india. J Med Virol. 2010; 82:1115-1125.

24. Wong VW, Chan SL, Mo F, Chan TC, Loong HH, Wong GL, Lui YY, Chan AT, Sung JJ, Yeo W, Chan HL, Mok TS. Clinical scoring system to predict hepatocellular carcinoma in chronic hepatitis b carriers. J Clin Oncol. 2010; 28:1660-1665.

25. Tseng TC, Liu CJ, Yang HC, Su TH, Wang CC, Chen CL, Kuo SF, Liu CH, Chen PJ, Chen DS, Kao JH. High levels of hepatitis b surface antigen increase risk of hepatocellular carcinoma in patients with low hbv load. Gastroenterology. 2012; 142:1140-1149.

26. Wu JC, Huang YH, Chau GY, Su CW, Lai CR, Lee PC, Huo TI, Sheen IJ, Lee SD, Lui WY. Risk factors for early and late recurrence in hepatitis b-related hepatocellular carcinoma. J Hepatol. 2009; 51:890-897.

27. Su CW, Chiou YW, Tsai YH, Teng RD, Chau GY, Lei HJ, Hung HH, Huo TI, Wu JC. The influence of hepatitis b viral load and pre-s deletion mutations on post-operative recurrence of hepatocellular carcinoma and the tertiary preventive effects by anti-viral therapy. PloS one. 2013; 8:e66457.

28. Sohn W, Paik YH, Lee MW, Rhim H, Lim HK, Cho JY, Gwak GY, Choi MS, Lee JH, Koh KC, Paik SW, Yoo BC. Predisposing factors for recurrence of hbv-related small hepatocellular carcinoma after percutaneous radiofrequency ablation. Scand J Gastroenterol. 2014; 49:373-380. 
29. Qu LS, Jin F, Huang XW, Shen XZ. High hepatitis b viral load predicts recurrence of small hepatocellular carcinoma after curative resection. J Gastrointest Surg. 2010; 14:1111-1120.

30. Liang TJ, Mok KT, Liu SI, Huang SF, Chou NH, Tsai CC, Chen IS, Yeh MH, Chen YC, Wang BW. Hepatitis b genotype c correlated with poor surgical outcomes for hepatocellular carcinoma. J Am Coll Surg. 2010; 211:580-586.

31. Li MR, Chen GH, Cai CJ, Wang GY, Zhao H. High hepatitis $b$ virus DNA level in serum before liver transplantation increases the risk of hepatocellular carcinoma recurrence. Digestion. 2011; 84:134-141

32. Kim JS, Kim W, So YH, Yu SJ, Kim BG. Topographical impact of hepatitis b-related hepatocellular carcinoma on local recurrence after radiofrequency ablation. J Clin Gastroenterol. 2014; 48:66-72.

33. Jang JW, Choi JY, Bae SH, Yoon SK, Woo HY, Chang UI, Kim CW, Nam SW, Cho SH, Yang JM, Lee CD. The impact of hepatitis b viral load on recurrence after complete necrosis in patients with hepatocellular carcinoma who receive transarterial chemolipiodolization: Implications for viral suppression to reduce the risk of cancer recurrence. Cancer. 2007; 110:1760-1767.

34. Chuma M, Hige S, Kamiyama T, Meguro T, Nagasaka A, Nakanishi K, Yamamoto Y, Nakanishi M, Kohara T, Sho T, Yamamoto K, Horimoto H, Kobayashi T, et al. The influence of hepatitis b DNA level and antiviral therapy on recurrence after initial curative treatment in patients with hepatocellular carcinoma. J Gastroenterol. 2009; 44:991-999.

35. An HJ, Jang JW, Bae SH, Choi JY, Cho SH, Yoon SK, Han JY, Lee KH, Kim DG, Jung ES. Sustained low hepatitis b viral load predicts good outcome after curative resection in patients with hepatocellular carcinoma. J Gastroenterol Hepatol. 2010; 25:1876-1882.

36. Hung IF, Wong DK, Poon RT, Fong DY, Chui AH, Seto WK, Fung JY, Chan AC, Yuen JC, Tiu R, Choi O, Lai CL, Yuen MF. Risk factors and post-resection independent predictive score for the recurrence of hepatitis b-related hepatocellular carcinoma. PloS one. 2016; 11:e0148493.

37. Sohn W, Paik YH, Kim JM, Kwon CH, Joh JW, Cho JY, Gwak GY, Choi MS, Lee JH, Koh KC, Paik SW, Yoo BC. Hbv DNA and hbsag levels as risk predictors of early and late recurrence after curative resection of hbv-related hepatocellular carcinoma. Ann Surgical Oncol. 2014; 21:2429-2435.

38. Kremsdorf D, Soussan P, Paterlini-Brechot P, Brechot C. Hepatitis b virus-related hepatocellular carcinoma: Paradigms for viral-related human carcinogenesis. Oncogene. 2006; 25:3823-3833.
39. Sung WK, Zheng H, Li S, Chen R, Liu X, Li Y, Lee NP, Lee WH, Ariyaratne PN, Tennakoon C, Mulawadi FH, Wong KF, Liu AM, et al. Genome-wide survey of recurrent hbv integration in hepatocellular carcinoma. Nat Genet. 2012; 44:765-769.

40. Chemin I, Zoulim F. Hepatitis b virus induced hepatocellular carcinoma. Cancer Lett. 2009; 286:52-59.

41. Chen C. Interaction of hepatitis b virus, chemical carcinogen, and genetic susceptibility: Multistage hepatocarcinogenesis with multifactorial etiology. Hepatology. 2002; 36:1046-1049.

42. Kubo S, Tanaka H, Takemura S, Yamamoto S, Hai S, Ichikawa T, Kodai S, Shinkawa H, Sakaguchi H, Tamori A, Habu D, Nishiguchi S. Effects of lamivudine on outcome after liver resection for hepatocellular carcinoma in patients with active replication of hepatitis b virus. Hepatol Res. 2007; 37:94-100.

43. Budhu A, Forgues M, Ye QH, Jia HL, He P, Zanetti KA, Kammula US, Chen Y, Qin LX, Tang ZY, Wang XW. Prediction of venous metastases, recurrence, and prognosis in hepatocellular carcinoma based on a unique immune response signature of the liver microenvironment. Cancer cell. 2006; 10:99-111.

44. Zhong R, Liu L, Tian Y, Wang Y, Tian J, Zhu BB, Chen W, Qian JM, Zou L, Xiao M, Shen N, Yang H, Lou J, et al. Genetic variant in swi/snf complexes influences hepatocellular carcinoma risk: A new clue for the contribution of chromatin remodeling in carcinogenesis. Sci Rep. 2014; 4:4147.

45. Stroup DF, Berlin JA, Morton SC, Olkin I, Williamson GD, Rennie D, Moher D, Becker BJ, Sipe TA, Thacker SB. Meta-analysis of observational studies in epidemiology: A proposal for reporting. JAMA. 2000; 283:2008-2012.

46. Bowden DS, Thompson A. New developments in hbv molecular diagnostics and quantitative serology. Hepatol Int. 2008; 2:3-11.

47. Greenland S, Longnecker MP. Methods for trend estimation from summarized dose-response data, with applications to meta-analysis. Am J Epidemiol. 1992; 135:1301-1309.

48. Larsson SC, Orsini N. Coffee consumption and risk of stroke: A dose-response meta-analysis of prospective studies. Am J Epidemiol. 2011; 174:993-1001.

49. Lau J, Ioannidis JP, Schmid CH. Quantitative synthesis in systematic reviews. Ann Intern Med. 1997; 127:820-826. 